https://doi.org/10.19195/0137-1134.127.12

\author{
ADRIANA KALICKA-MIKOŁAJCZYK \\ ORCID: 0000-0002-1250-5052 \\ Uniwersytet Wrocławski
}

\title{
UNIA EUROPEJSKA JAKO PROMOTOR WARTOŚCI NA ARENIE MIĘDZYNARODOWEJ
}

\begin{abstract}
Abstrakt: Na podstawie art. 3 ust. 5 Traktatu o Unii Europejskiej (TUE) na Unię Europejską (UE) nałożony został obowiązek umacniania i propagowania swoich wartości na arenie międzynarodowej. Wartości te wymienione są w postanowieniach art. 2 TUE; zgodnie z nimi „Unia opiera się na wartościach poszanowania godności osoby ludzkiej, wolności, demokracji, równości, państwa prawnego, jak również poszanowania praw człowieka". Następnie zostały one powtórzone w postanowieniach art. 21 ust. 1 TUE jako zasady działań zewnętrznych UE. W postanowieniach niniejszego ustępu możemy przeczytać, że działania UE na arenie międzynarodowej oparte są na zasadach, które leżą u podstaw jej utworzenia i rozwoju, oraz które zamierza wspierać na świecie: demokracji, państwa prawnego, powszechności i niepodzielności praw człowieka i podstawowych wolności, poszanowania godności ludzkiej, zasad równości i solidarności oraz poszanowania zasad Karty Narodów Zjednoczonych oraz prawa międzynarodowego. Niniejszy artykuł zawiera propedeutyczną analizę działań UE na arenie międzynarodowej mających na celu promowanie wartości w relacjach z podmiotami trzecimi. Jego zasadniczym celem jest udzielenie odpowiedzi na następujące pytania: czym są wartości i jaką rolę pełnią w unijnym porządku prawnym, oraz w jaki sposób UE wywiązuje się z nałożonego na nią obowiązku polegającego na promowaniu wartości na arenie międzynarodowej.
\end{abstract}

Słowa kluczowe: Unia Europejska, wartości, polityka zewnętrzna, umowa międzynarodowa, preferencje handlowe

\section{UWAGI WPROWADZAJĄCE}

Ogólne cele polityki zewnętrznej Unii Europejskiej (UE) zostały sformułowane w art. 3 ust. 5 Traktatu o Unii Europejskiej (TUE), zgodnie z postanowieniami którego w stosunkach zewnętrznych UE umacnia i propaguje swoje wartości $\mathrm{i}$ interesy oraz wnosi wkład w ochronę swoich obywateli ${ }^{1}$. Następnie zostały one uszczegółowione w postanowieniach art. 21 ust. 2 TUE, który stwierdza, że UE

1 Traktat o Unii Europejskiej (wersja skonsolidowana z 2016 roku), Dz.U. C 2002 z 7 czerwca 2016 roku. 
określa i prowadzi wspólne polityki i działania mające na celu ochronę swoich wartości, umacnianie i wspieranie demokracji, państwa prawnego, praw człowieka i zasad prawa międzynarodowego. Zauważalne jest zatem, że na pierwszym miejscu wśród celów polityki zewnętrznej znajduje się ten, który wprost odnosi się do umacniania i ochrony unijnych wartości na arenie międzynarodowej. Na uwagę zasługuje również to, że zostały one opisane w sposób ogólny i mało precyzyjny, co skutkuje tym, iż instytucje UE dysponują ogromną swobodą przy konstruowaniu instrumentów ich realizacji. Jednocześnie istnieje realne niebezpieczeństwo przyjmowania wielu działań nieraz pozostających ze sobą w sprzeczności ${ }^{2}$. Ponadto nie istnieje między nimi hierarchia, nie ma celów bardziej lub mniej ważnych. Są one wspólne dla całej $U^{3}$. Wart podkreślenia jest również fakt, że podobny zapis znajdziemy w innych unijnych dokumentach, takich jak Europejska Strategia Bezpieczeństwa oraz Globalna strategia na rzecz polityki zagranicznej i bezpieczeństwa UE. Pierwszy z dokumentów wśród unijnych celów polityki zewnętrznej wymieniał propagowanie swoich wartości ${ }^{4}$. Bardzo podobny zapis znajdziemy w przyjętej w 2016 roku Globalnej strategii na rzecz polityki zagranicznej i bezpieczeństwa UE. Zgodnie z jej postanowieniami „UE będzie promować odporność swoich demokracji i pozostanie wierna wartościom, które były inspiracją do jej stworzenia i rozwoju. Obejmują one poszanowanie i upowszechnianie praw człowieka, podstawowych wolności i praworządności"5.

Zasadniczym celem niniejszego artykułu jest udzielenie odpowiedzi na dwa pytania: po pierwsze, czym są wartości i jaką rolę pełnią w polityce zewnętrznej UE, i po drugie, w jaki sposób (ewentualnie jakie sposoby) UE wypełnia nałożony na nią traktatowy obowiązek polegający na promowaniu wartości na arenie międzynarodowej.

\section{WARTOŚCI W TRAKTACIE Z LIZBONY}

Wartości możemy zdefiniować jako „podstawowe nastawienia społeczeństwa lub jednostek charakteryzujące się szczególną mocą i przekonaniem o ich prawdziwości"' ${ }^{\prime}$. Z uwagi na to, że pełnią one funkcję orientowania i porządkowania normatywnego, określając, co jest dobre, a co złe, odgrywają rolę prawnych

2 M. Zieliński, Pojęcie i rodzaje polityk Wspólnoty Europejskiej, [w:] Polska i Wielka Brytania wobec Unii Europejskiej. Wybrane zagadnienia prawne, red. G. Grabowska, Katowice 2002, s. 242.

3 C. Mik, Traktat o Unii Europejskiej. Komentarz, Łódź 2005, s. 59.

4 Sekretariat Generalny Rady Unii Europejskiej, Bezpieczna Europa w lepszym świecie. Europejska Strategia Bezpieczeństwa, „Monitor Integracji Europejskiej” 2004, nr 70, s. 6.

5 Globalna strategia na rzecz polityki zagranicznej i bezpieczeństwa UE, https://europa.eu/ globalstrategy/sites/globalstrategy/files/eugs_pl_version.pdf (dostęp: 15.01.2021).

${ }^{6}$ M. Zieliński, Wartości Unii Europejskiej, [w:] Ubi Ius, Ibi Remedium. Księga dedykowana pamięci Profesora Jana Kolasy, red. B. Krzan, Wrocław 2016, s. 652. 
standardów moralności lub sprawiedliwości dla norm prawnych. Z tego powodu możemy je umiejscowić pomiędzy prawem a moralnością. W przypadku UE art. 2 TUE ustanawia wartości, na których oparta jest UE, i są to wartości podstawowe i wspólne dla wszystkich państw członkowskich. Zgodnie z jego postanowieniami UE opiera się na wartościach poszanowania godności osoby ludzkiej, wolności, demokracji, równości, państwa prawnego, jak również poszanowania praw człowieka, w tym praw osób należących do mniejszości. Wartości te są wspólne państwom członkowskim w społeczeństwie opartym na pluralizmie, tolerancji, sprawiedliwości, solidarności oraz równości kobiet i mężczyzn. Jest to katalog spójny i zamknięty. Artykuł ten jest podstawową regulacją materialną, do której odwołują się inne artykuły: 3, 7, 8, 21 i 49 TUE, co czyni z wartości centralną kategorię normatywną dla unijnego porządku prawnego oraz podkreśla jej nadrzędność nad ogólnymi zasadami prawa. Jak słusznie wskazuje Marek Zieliński, przepis ten pełni funkcję zasady homogeniczności z uwagi na fakt, że stanowi on zasadę prawną, która nadaje unijnemu porządkowi prawnemu i porządkom krajowym państw członkowskich pewien stopień zgodności umożliwiający im dalszą koegzystencję 7 .

Poszanowanie wartości w unijnym porządku prawnym zapewnia Trybunał Sprawiedliwości (TS), który kieruje się tradycjami konstytucyjnymi wspólnymi dla państw członkowskich oraz wskazówkami znajdującymi się w umowach międzynarodowych dotyczących ochrony praw człowieka, przy których tworzeniu państwa członkowskie współpracowały lub do których przystąpiły. Szczególne znaczenie ma w tym kontekście Europejska konwencja o ochronie praw człowieka i podstawowych wolności oraz inne międzynarodowe instrumenty ochrony praw człowieka. Dla przykładu w wyroku w sprawie International Transport Workers' Federation i Finnish Seamen's Union w zakresie prawa do strajku bezpośrednio odwołał się do Europejskiej karty społecznej oraz Konwencji nr 87 dotyczącej wolności związkowej i ochrony praw związkowych przyjętej przez Międzynarodową Organizację Pracy ${ }^{8}$. W wyroku w sprawie Schmidberger potwierdził, że ,środki sprzeciwiające się poszanowaniu praw człowieka są nie do zaakceptowania w Unii" 9 . W wyroku w sprawie Parlament przeciwko Radzie dotyczącej zawarcia Umowy między UE a Zjednoczoną Republiką Tanzanii w sprawie warunków przekazywania przez siły morskie dowodzone przez UE do Zjednoczonej Republiki Tanzanii osób podejrzanych o piractwo i zajętego w związku z tym mienia, expressis verbis orzekł, że „poszanowanie zasad państwa prawa i praw człowieka, a także godności ludzkiej należy zapewnić w każdym działaniu Unii, co wynika

${ }^{7}$ Ibidem, s. 651.

${ }^{8}$ Sprawa C-438/05, International Transport Workers' Federation i Finnish Seamen's Union p. Viking Line ABP $i$ OÜ Viking Line Eesti, ECLI:EU:C:2007:772, pkt 43.

${ }^{9}$ Sprawa C-112/00, Eugen Schmidberger, Internationale Transporte und Planzüge $p$. Republik Österreich, ECLI:EU:C:2003:333, pkt 73. 
z art. 21 ust. 1 akapit pierwszy, art. 21 ust. 2 lit. b) i art. 21 ust. 3 TUE" ${ }^{10}$. W wyroku w sprawie Portugalia przeciwko Radzie orzekł, że unijna polityka współpracy na rzecz rozwoju musi uwzględniać zasady demokracji, rządów prawa i praw człowieka stanowiące istotny element współpracy w tym obszarze, a ich naruszenie może stanowić podstawę do zawieszenia współpracy z dopuszczającym się tego państwem ${ }^{11}$. Ponadto wskazał, że wartości te są nadrzędne w stosunku do innych obszarów współpracy i to właśnie po stronie UE leży obowiązek ich uwzględniania w procesie decyzyjnym mającym na celu nawiązanie współpracy z państwem trzecim. Do wartości odniósł się również w wyroku w sprawie Kadi, w którym orzekł, że „zobowiązania nałożone umową międzynarodową nie mogą skutkować naruszeniem zasad konstytucyjnych traktatu UE, wśród których znajduje się zasada, zgodnie z którą wszystkie akty wspólnotowe powinny przestrzegać praw podstawowych, przy czym przestrzeganie to stanowi przesłankę ich zgodności z prawem, a kontrola, czy przesłanka ta jest spełniona, należy do Trybunału w ramach zupełnego systemu środków prawnych ustanowionego w tym traktacie"12. W wyroku tym zwrócił uwagę, że zaciągnięte przez UE zobowiązania na arenie międzynarodowej nie mogą przeważać nad prawem pierwotnym, którego elementem składowym są prawa podstawowe.

Konkluzje wynikające ze wszystkich cytowanych wyroków są takie, że: po pierwsze, wartości stanowią podstawę funkcjonowania UE, a ich propagowanie jest celem UE wymienionym expressis verbis w postanowieniach Traktatu z Lizbony; po drugie, stanowią one wartość nadrzędną nad innymi obszarami współpracy, na przykład ekonomicznym czy handlowym; po trzecie, UE zobowiązana jest uwzględniać wartości w procesie programowania współpracy z podmiotami trzecimi; i po czwarte, naruszenie wartości przez państwo trzecie może skutkować zawieszeniem współpracy z UE. Wartości zatem wyznaczają standardy ustrojowe nie tylko dla państw członkowskich, ale również dla państw trzecich. $\mathrm{Z}$ tego powodu zajmują one bardzo szczególne i uprzywilejowane miejsce w systemie prawa $\mathrm{UE}^{13}$.

10 Sprawa C-263/14, Parlament p. Radzie, ECLI:EU:C:2016:435, pkt 47.

11 Sprawa C-268/94, Portugalia p. Radzie, ECLI:EU:C:1996:461, pkt 24 i 25.

12 Sprawy połączone C-402/05 P oraz C-415/05 P, Yassin Abdullah Kadi i Al Barakaat International Foundation p. Radzie Unii Europejskiej i Komisja Wspólnot Europejskich, ECLI:EU:C:2008:461, pkt 285, 306 i 308.

13 A. Cieśliński, Wartości Unii Europejskiej jako wartości konstytucyjne, „Przegląd Prawa i Administracji” 91, 2012, s. 11-26; K. Lenaerts, Wartości Unii Europejskiej a pluralizm konstytucyjny, „Europejski Przegląd Sądowy” 2014, nr 9, s. 4-6; Ł.J. Pikuła, Aksjologia Unii Europejskiej w świetle źródel, wykładni i instytucji, Toruń 2015. 


\section{DZIAŁANIA UNII EUROPEJSKIEJ NA ARENIE MIĘDZYNARODOWEJ MAJĄCE NA CELU PROMOWANIE WARTOŚCI}

W komunikacie zatytułowanym „Rola Unii Europejskiej w promowaniu praw człowieka i demokracji w państwach trzecich" Komisja Europejska stwierdziła, że UE stopniowo definiowała siebie w kontekście promowania praw człowieka i demokratycznych wolności ${ }^{14}$. Od czasu wejścia w życie postanowień TUE wartości stały się niezwykle ważnym elementem unijnych polityk zewnętrznych. Możemy powiedzieć, że stały się one nieodłącznym elementem jej rozwoju oraz fundamentem jej tożsamości ${ }^{15}$. W jaki zatem sposób UE promuje wartości na arenie międzynarodowej? Przyglądając się bliżej jej działalności na scenie międzynarodowej, zauważamy, że odbywa się to za pomocą różnych instrumentów, spośród których do „najpopularniejszych” należy zaliczyć: 1) instrumenty pomocy finansowej i technicznej, 2) jednostronne instrumenty handlowe, 3) umowy międzynarodowe oraz 4) instrumenty niewiążące prawnie.

\subsection{INSTRUMENTY POMOCY FINANSOWEJ I TECHNICZNEJ}

Unijne programy pomocy finansowej i technicznej promują wartości w dwojaki sposób. Po pierwsze bezpośrednio, za pomocą specjalnie w tym celu ustanowionego instrumentu finansowego na rzecz wspierania demokracji i praw człowieka na świecie, którego zasadniczym celem jest zapewnienie wsparcia na rzecz rozwijania i umacniania demokracji i praworządności, a także poszanowania wszystkich praw człowieka i podstawowych wolności ${ }^{16}$. Po drugie pośrednio, za pomocą innych instrumentów wsparcia finansowego i technicznego, których jednym z celów wsparcia jest propagowanie praw człowieka i podstawowych wolności, praworządności, zasad równości i walki z wszelkimi formami dyskryminacji, ustanowienie głębokiej i trwałej demokracji, propagowanie dobrych rządów, walkę z korupcją, wzmacnianie zdolności instytucjonalnych na wszystkich szczeblach oraz rozwój dobrze prosperującego społeczeństwa obywatelskiego z udziałem partnerów społecznych. Dotyczy to następujących instrumentów: Europejskiego Instrumentu Sąsiedztwa, Instrumentu Pomocy Przedakcesyjnej, Instrumentu Finansowania

14 Communication from the Commission to the Council and the European Parliament, The European's Union Role in Promoting Human Rights and Democracy in Third Countries, COM (2001) 252 final, s. 7.

15 A. Kalicka- Mikołajczyk, Wartości w polityce zewnętrznej Unii Europejskiej, [w:] Wspólne wartości prawa międzynarodowego, europejskiego i krajowego, red. E. Cała-Wacinkiewicz, J. Menkes, Warszawa 2018, s. 267-286.

16 Rozporządzenie Parlamentu Europejskiego i Rady (UE) nr 235/2014 z dnia 11 marca 2014 roku ustanawiające instrument finansowy na rzecz wspierania demokracji i praw człowieka na świecie, Dz.U. L 77 z 15 marca 2014 roku, s. 85-94. 
Współpracy na rzecz Rozwoju czy Instrumentu Partnerstwa na rzecz Współpracy z Państwami Trzecimi.

\subsection{JEDNOSTRONNE INSTRUMENTY HANDLOWE}

Promowanie wartości za pomocą jednostronnych instrumentów handlowych obejmuje ogólny unijny system preferencji taryfowych (tak zwany system GSP) ${ }^{17}$. Jego celem jest ułatwienie krajom i tery toriom rozwijającym się dostępu do rynku UE dzięki obniżeniu stawek celnych na ich towary. Pierwotnie UE przyznawała jednostronne preferencje taryfowe, aby kraje rozwijające się mogły generować dodatkowe dochody z wywozu z przeznaczeniem na inwestycje we własny zrównoważony rozwój. W ramach przeprowadzonej w 2012 roku reformy system GSP przekierowano $\mathrm{w}$ większym stopniu na kraje najbardziej potrzebujące, tak zwane najsłabiej rozwinięte, utrzymując jednak jego trzy elementy. Pierwszym z nich jest standardowy system GSP, który stanowi autonomiczne rozwiązanie handlowe, za którego pośrednictwem UE udziela dla niektórych zagranicznych towarów jednostronnego preferencyjnego dostępu do rynku UE w postaci obniżonych lub zerowych stawek celnych. Drugi element - GSP Plus - stanowi konkretne zachęty w postaci redukcji ceł dla krajów w gorszym położeniu, które ratyfikowały i wdrożyły międzynarodowe konwencje dotyczące praw człowieka i prawa pracy oraz środowiska i dobrych rządów. Szczególne rozwiązanie motywacyjne dotyczące zrównoważonego rozwoju i dobrych rządów - GSP Plus - nie nakłada żadnego cła w przypadku mniej więcej $66 \%$ wszystkich pozycji taryfowych przewidzianych w ramach standardowego ogólnego systemu preferencji dla krajów rozwijających się uznawanych za podatne na zagrożenia. Jest to jednak uzależnione od ratyfikowania i wprowadzenia w życie 27 międzynarodowych konwencji dotyczących zrównoważonego rozwoju, w tym dotyczących podstawowych praw człowieka, praw pracowniczych, a także ochrony środowiska oraz konwencji dotyczących walki z nielegalną produkcją i przemytem narkotyków. Konsekwencją niezastosowania się do tych wymagań jest zawieszenie ulg celnych.

\subsection{UMOWY MIĘDZYNARODOWE}

W przypadku promowania wartości za pośrednictwem zawieranych umów międzynarodowych odrębnej analizy wymagają dwa przypadki: zawarcie traktatu akcesyjnego oraz zawarcie innej umowy międzynarodowej. Wartości stanowią warunek sine qua non członkostwa w UE. Zgodnie z postanowieniami art. 49 TUE o członkostwo w UE ubiegać może się wyłącznie państwo europejskie, ,które szanuje wartości, o których mowa w artykule 2, i zobowiązuje się je wspierać".

17 Rozporządzenie Parlamentu Europejskiego i Rady (UE) nr 978/2012 z dnia 25 października 2012 roku wprowadzające ogólny system preferencji taryfowych i uchylające rozporządzenie Rady (WE) nr 732/2008, Dz.U. L 303 z 31 października 2012 roku, s. 1-82. 
Dodatkowo podczas szczytu Rady Europejskiej w Kopenhadze w 1993 roku sformułowane zostały kryteria (tak zwane kryteria kopenhaskie), które muszą być spełnione przez państwo ubiegające się o przyjęcie do UE. Na pierwszym miejscu wymienione zostały stabilność instytucji gwarantujących demokrację, praworządność, prawa człowieka oraz poszanowanie i ochrona mniejszości. Zatem postanowienie traktatu dotyczące akcesji zachowuje więź pomiędzy członkostwem w UE i przestrzeganiem wartości. Państwo kandydujące nie tylko ma obowiązek przestrzegania wartości, ale również ich wspierania. „Kryteria kwalifikacji uzgodnione przez Radę Europejską brane są pod uwagę" jako dodatkowa część procesu akcesji.

Dalej, w 1995 roku, Komisja Europejska przyjęła komunikat dotyczący włączenia klauzuli dotyczącej przestrzegania zasad demokratycznych i praw człowieka do umów międzynarodowych zawieranych przez UE z państwami trzecimi ${ }^{18}$. To właśnie od tego czasu klauzula ta stanowi zasadniczy element następujących umów międzynarodowych: stowarzyszeniowych, o współpracy, handlowych czy o partnerstwie i współpracy. Klauzulę taką znajdziemy zatem w art. 2 Umowy o współpracy pomiędzy Wspólnotą Europejską a Republiką Południowej Afryki; art. 2 Układu o stabilizacji i stowarzyszeniu między Wspólnotami Europejskimi a Bośnią i Hercegowiną; art. 2 Układu o stowarzyszeniu między UE a Ukrainą; art. 2 Umowy o partnerstwie między członkami grupy państw Afryki, Karaibów i Pacyfiku a Wspólnotą Europejską czy w art. 2 Umowy o Partnerstwie i współpracy pomiędzy Wspólnotą Europejską a Armenią. Na uwagę zasługuje jednak, że nie istnieje jeden „zunifikowany” schemat takiej klauzuli. Oznacza to, że różnią się one od siebie treścią, wszystko zależy od tego, jakiego kraju one dotyczą. Dla przykładu umowy stowarzyszeniowe pomiędzy UE a państwami Europy Środkowej, Wschodniej i Bałkanów Zachodnich zawierają odwołanie do zasad Organizacji Bezpieczeństwa i Współpracy w Europie (OBWE), natomiast umowy stowarzyszeniowe zawierane z państwami pozaeuropejskimi - odwołanie do zasad Powszechnej Deklaracji Praw Człowieka. I tak art. 2 układu stowarzyszeniowego UE-Ukraina ma następujące brzmienie:

Poszanowanie zasad demokratycznych, praw człowieka i podstawowych wolności, określonych w szczególności w akcie końcowym z Helsinek Konferencji Bezpieczeństwa i Współpracy w Europie z 1975 roku oraz Paryskiej karcie dla nowej Europy z 1990 roku, a także innych właściwych instrumentach z zakresu praw człowieka, w tym Powszechnej deklaracji praw człowieka ONZ i Konwencji o ochronie praw człowieka i podstawowych wolności, oraz poszanowanie zasady praworządności są podstawą wewnętrznej i zewnętrznej polityki Stron oraz stanowią istotne elementy niniejszego Układu. Propagowanie poszanowania zasady suwerenności i integralności terytorialnej, nienaruszalności granic i niepodległości, a także zwalczanie rozprzestrzeniania broni masowego rażenia, związanych z nią materiałów oraz systemów ich przenoszenia również stanowią istotne elementy niniejszego Układu.

18 Communication from the Commission on the Inclusion of Respect for Democratic Principles and Human Rights in Agreements Between the Community and Third Countries, COM (95) 216 final. 
Z kolei art. 2 Umowy w sprawie handlu, rozwoju i współpracy między UE a Republiką Południowej Afryki ma następujące brzmienie:

Zasadniczym elementem niniejszej Umowy oraz podstawą wewnętrznej i międzynarodowej polityki Wspólnoty i Republiki Południowej Afryki jest poszanowanie zasad demokracji oraz podstawowych praw człowieka, ustanowionych w Powszechnej Deklaracji Praw Człowieka. Strony potwierdzają także swoje przywiązanie do zasad dobrych rządów.

Jak wskazał TS w sprawie pomiędzy Portugalią i Radą, dotyczącej Umowy o współpracy pomiędzy UE a Indiami, klauzula stanowi istotny element tej umowy, a w przypadku jej poważnego naruszenia, może doprowadzić do zawieszenia lub wygaśnięcia. Potwierdzone to zostało również w późniejszym orzeczeniu wydanym w dniu 16 czerwca 1998 roku w sprawie Racke, które dotyczyło ważności rozporządzenia zawieszającego koncesje handlowe ustanowione w Umowie o współpracy między Europejską Wspólnotą Gospodarczą a Socjalistyczną Federacyjną Republiką Jugosławii na skutek naruszenia pokoju, zasad dobrosąsiedzkiej współpracy, które stanowiły warunek nawiązania i realizacji współpracy przewidzianej w niniejszej umowie ${ }^{19}$.

\subsection{INSTRUMENTY NIEWIĄŻĄCE PRAWNIE}

Promowanie wartości za pomocą instrumentów niewiążących prawnie obejmuje zwłaszcza: dialogi na temat praw człowieka, klucze tematyczne poświęcone prawom człowieka, budowanie konsensusu oraz porozumienia niewiążące prawnie zawierane na przykład w ramach Europejskiej Polityki Sąsiedztwa.

W dniu 22 grudnia 2008 roku Rada przyjęła Wytyczne w sprawie dialogu na temat praw człowieka prowadzonego z państwami trzecimi ${ }^{20}$. UE zobowiązała się do zintensyfikowania procesu włączania kwestii dotyczących praw człowieka i demokratyzacji do wszelkich aspektów swojej polityki zewnętrznej. Oznacza to, że zagadnienia powyższe będą omawiane na wszystkich szczeblach, nie tylko ministerialnych, ale również wspólnych komitetów, dialogu prowadzonego przez Prezydencję Rady, trojkę, szefów misji oraz Komisję Europejską. Cele dialogów będą zatem się różnić w poszczególnych przypadkach, gdyż będą ustalane stosownie do okoliczności. Inicjatywa podjęcia dialogu może wyjść od UE, ale może go zaproponować także państwo trzecie. W chwili obecnej UE prowadzi dialogi z ponad 40 państwami trzecimi, które przybierają różne formy. Po pierwsze dialogu o charakterze ogólnym, opartego na regionalnych lub dwustronnych traktatach, prowadzonych w ramach partnerstw strategicznych, a obejmujących: państwa kandydujące do UE, zwłaszcza Bałkanów Zachodnich, państwa Afryki, Karaibów i Pacyfiku, państwa Ameryki Łacińskiej, państwa Afryki Północnej, państwa

19 Sprawa C-162/96, A. Racke GmbH \& Co. p. Hauptzollamt Mainz, ECLI:EU:C:1998:293.

20 Rada Unii Europejskiej, Wytyczne w sprawie dialogu na temat praw człowieka prowadzonego z państwami trzecimi, Bruksela 2008, Doc. 16526/08. 
Kaukazu Południowego oraz dialogu prowadzonego w ramach Stowarzyszenia Azji Południowo-Wschodniej oraz dialogu Azja-Europa. Po drugie zinstytucjonalizowanego dialogu dotyczącego praw człowieka prowadzonego z Chinami, Rosją i Unią Afrykańską. Po trzecie dialogu ad hoc obejmującego co do zasady inne kwestie, na przykład dotyczące Wspólnej Polityki Zagranicznej i Bezpieczeństwa, jednakże zawierającego również ustalenia dotyczące ochrony praw człowieka prowadzone na przykład z Sudanem oraz po czwarte dialogu w ramach szczególnych stosunków z niektórymi państwami trzecimi opierającego się na dużej zbieżności stanowisk, prowadzonego z: USA, Kanadą, Japonią i Nową Zelandią.

W przypadku drugiej grupy, a mianowicie wytycznych tematycznych dotyczących praw człowieka, wskazać należy cztery dokumenty: Wytyczne UE w sprawie praw człowieka dotyczące niedyskryminacji w działaniach zewnętrznych przyjęte przez Radę 18 marca 2019 roku, Wytyczne UE na temat obrońców praw człowieka przyjęte przez Radę w dniu 6 lutego 2008 roku, Wytyczne UE w sprawie dzieci w konfliktach zbrojnych przyjęte przez Radę w dniu 5 czerwca 2008 roku oraz Wytyczne UE w sprawie promowania przestrzegania międzynarodowego prawa humanitarnego przyjęte przez Radę w dniu 23 grudnia 2005 roku i uaktualnione w dniu 15 grudnia 2009 roku $^{21}$.

Zakaz dyskryminacji jest jedną z najważniejszych zasad międzynarodowego prawa dotyczącego praw człowieka. Od przyjęcia Powszechnej Deklaracji Praw Człowieka w Paryżu w 1948 roku w dalszym ciągu kładzie się nacisk na tę zasadę w instrumentach dotyczących praw człowieka, które opracowano i włączono do prawodawstwa krajowego $\mathrm{w}$ większości państw na świecie. Zakaz dyskryminacji stanowi jedną z podstawowych zasad traktatów założycielskich. Dyskryminacja może prowadzić do niepokojów społecznych, przemocy, konfliktów i przymusowego wysiedlenia. Poza wysokimi kosztami ludzkimi dyskryminacja powoduje ogromne koszty gospodarcze, to jest ubóstwo i utratę możliwości, nie tylko dla pojedynczych osób i ich rodzin, ale również dla całych społeczeństw. Zgodnie z zapisami zawartymi w wytycznych UE będzie wykorzystywała wszystkie unijne narzędzia, instrumenty i działania mające na celu zwalczanie dyskryminacji w unijnej polityce dotyczącej praw człowieka w działaniach zewnętrznych, takie jak: dialogi polityczne i współpraca bilateralna, sprawozdania szefów misji UE, démarche i oświadczenia publiczne, wizyty urzędników UE wysokiego szczebla w misjach UE i misjach państw członkowskich w państwach trzecich, zajmowanie się dyskryminacją w ramach unijnej współpracy na rzecz rozwoju i pomocy hu-

${ }^{21}$ Rada Unii Europejskiej, Wytyczne UE w sprawie praw człowieka dotyczace niedyskryminacji $w$ działaniach zewnętrznych, Bruksela 2019, Doc. 6337/19; Council of the European Union, Ensuring protection. European Union Guidelines on Human Rights Defenders, https://eeas.europa. eu/sites/eeas/files/eu guidelines hrd en.pdf (dostęp: 2.01.2021); Council of the European Union, EU Guidelines on Children and Armed Conflict, Bruksela 2008, Doc. 10019/08; Updated European Union Guidelines on Promoting Compliance with International Humanitarian Law (IHL), Dz.U. C 303 z 15 grudnia 2009, s. 12-17. 
manitarnej, zajmowanie się dyskryminacją w ramach współpracy wielostronnej na przykład na forum Rady Europy, ONZ, OBWE, MOP, zajmowanie się dyskryminacją poprzez wspieranie wysiłków społeczeństwa obywatelskiego, które odgrywa kluczową rolę w propagowaniu niedyskryminacji na szczeblu lokalnym, krajowym, regionalnym i międzynarodowym. W drugim $\mathrm{z}$ dokumentów określono podejście UE do wspierania i ochrony obrońców praw człowieka w państwach spoza UE w celu umożliwienia im swobodnego działania. Dyplomaci na misjach UE zobowiązani zostali do odbywania regularnych spotkań z obrońcami praw człowieka, odwiedzania zatrzymanych działaczy, monitorowania przebiegu procesów i wstawiania się za ich ochroną. Urzędnicy UE wysokiego szczebla, na przykład Wysoki Przedstawiciel Unii ds. Zagranicznych i Polityki Bezpieczeństwa, będą odbywali spotkania z obrońcami praw człowieka w planie swoich wizyt do krajów spoza UE. Prowadzony dialog z państwem trzecim będzie również dotyczył kwestii związanych ochroną obrońców praw człowieka. UE zobowiązała się również do udzielania wsparcia finansowego tej grupie osób. Według danych UNICEF jedno na dziesięcioro dzieci na świecie żyje w obszarach dotkniętych konfliktem zbrojnym, co stanowi zagrożenie dla ich życia, rozwoju i możliwości życiowych. $Z$ tego powodu celem trzeciego z dokumentów jest nakłonienie rządów i organizacji na całym świecie do stosowania prawa humanitarnego oraz praw człowieka w celu ochrony dzieci przed skutkami konfliktu zbrojnego, a także do niewerbowania dzieci do służby w grupach zbrojnych oraz ukrócenia bezkarności w przypadku przestępstw przeciwko dzieciom. Podkreślenia wymaga również zaangażowanie się UE we wsparcie kampanii Children, Not Soldiers, która rozpoczęła się w 2014 i trwała do końca 2016 roku, a na celu miała powstrzymanie wcielania dzieci do armii i wykorzystywania ich jako żołnierzy. Celem czwartego z dokumentów jest natomiast dostarczenie UE, jej instytucjom i organom sprawnych narzędzi promowania przestrzegania międzynarodowego prawa humanitarnego. Podkreślają one zaangażowanie UE w promowanie przestrzegania tego prawa w widoczny i konsekwentny sposób. Wytyczne są adresowane do wszystkich podmiotów działających w ramach UE w zakresie, w jakim podnoszone kwestie mieszczą się w ich obszarach odpowiedzialności i kompetencji.

Najlepszym przykładem budowania konsensusu jest kampania UE na rzecz porozumienia w sprawie zniesienia kary śmierci. Wytyczne w tej sprawie zostały po raz pierwszy przyjęte w roku 1998, a następnie zmienione i uaktualnione w dniu 5 czerwca $2008^{22}$. W dokumencie możemy przeczytać, że

UE uważa, iż zniesienie kary śmierci przyczynia się do umocnienia godności osoby ludzkiej i do stopniowego rozwijania praw człowieka. $Z$ tego powodu UE stawia sobie za cel działać na rzecz powszechnego zniesienia kary śmierci oraz apelować o stopniowe odchodzenie od kary śmierci w państwach, w których ona nadal obowiązuje ${ }^{23}$.

${ }^{22}$ Rada Unii Europejskiej, Wytyczne w sprawie kary śmierci: wersja zweryfikowana i uaktualniona, Bruksela 2008, Doc. 10015/08.

23 Ibidem, s. 3-4. 
Kampania UE prowadzona jest zarówno na poziomie bilateralnym, jak i wielostronnym. Podejmowane inicjatywy przyjmują różne formy. Najczęściej są to deklaracje lub dèmarches $\mathrm{w}$ sprawie kary śmierci, które mogą przybrać formę dialogu i konsultacji z państwem trzecim lub innej formy, która będzie uzależniona od konkretnego przypadku. Wytyczne spełniają zatem dwie podstawowe funkcje. Po pierwsze mają zapewnić spójność w ramach konkretnego zagadnienia w sytuacji, gdy UE zdefiniowała swoje cele, ale również są publicznym oświadczeniem wskazującym stanowisko UE w danej szczególnej kwestii ${ }^{24}$. Prowadzona przez UE polityka w powyższej kwestii posiada również wymiar praktyczny. Artykuł 13 Umowy o Ekstradycji między Unią Europejską a Stanami Zjednoczonymi Ameryki przewiduje, że

w przypadku, gdy przestępstwo w odniesieniu, do którego wnosi się o ekstradycję, jest zagrożone karą śmierci według prawa państwa wnioskującego i nie jest zagrożone karą śmierci według prawa państwa, do którego się wnioskuje, państwo wezwane może wyrazić zgodę na ekstradycję pod warunkiem, że kara śmierci nie zostanie orzeczona w odniesieniu do poszukiwanej osoby lub, jeżeli ze względów proceduralnych taki warunek nie może zostać spełniony przez państwo wzywające, pod warunkiem, że jeżeli kara śmierci zostanie orzeczona, nie zostanie wykonana. Jeżeli państwo wzywające akceptuje ekstradycję z zastrzeżeniem warunków na mocy niniejszego artykułu, spełnia te warunki. Jeżeli państwo wzywające nie akceptuje warunków, wniosek o ekstradycję może zostać odrzucony ${ }^{25}$.

W dniu 6 marca 2009 roku doszło do zawarcia umowy przez UE i Kenię w sprawie warunków i trybu przekazywania Kenii przez EUNAVFOR osób podejrzanych o popełnienie aktów piractwa przetrzymywanych przez siły morskie dowodzone przez Unię Europejską (EUNAVFOR) oraz zajętego mienia będącego w posiadaniu EUNAVFOR-u, a także traktowania osób i mienia po takim przekazaniu $^{26}$. Zgodnie $\mathrm{z}$ jej postanowieniami na żadnej osobie przekazanej nie zostanie wykonana kara śmierci. Kenia podejmie zgodnie z mającymi zastosowanie przepisami odpowiednie kroki, aby zagwarantować, że kara śmierci przewidziana w jakimkolwiek wyroku zostanie zastąpiona karą pozbawienia wolności. Na forum wielostronnym, zgodnie z zapisami Wytycznych, UE będzie zgłaszała wszelkie inicjatywy służące wprowadzeniu moratorium na stosowanie kary śmierci; będzie dążyła do tego, by w dokumentach sporządzanych na takich forach znalazły się wzmianki o ustanowieniu moratorium na egzekucje i o zniesieniu kary śmierci,

${ }^{24}$ M. Cremona, Values in EU Foreign Policy, [w:] Beyond the Established Legal Order. Policy Interconnections between the EU and the Rest of the World, red. M. Evans, P. Koutrakos, Oxford 2011, s. 309.

25 Agreement on Extradition Between the European Union and the United States of America, Dz.U. L 181 z 19 lipca 2003, s. 27-33.

26 Wymiana listów między Unią Europejską a rządem Kenii w sprawie warunków i trybu przekazywania Kenii przez EUNAVFOR osób podejrzanych o popełnienie aktów piractwa przetrzymywanych przez siły morskie dowodzone przez Unię Europejską (EUNAVFOR) oraz zajętego mienia będącego w posiadaniu EUNAVFOR-u, a także traktowania osób i mienia po takim przekazaniu, Dz.U. L 79 z 25 marca 2009 roku, s. 47-59. 
oraz zachęcała organizacje międzynarodowe do podjęcia działań, które miałyby na celu skłonienie państw do podpisania i ratyfikowania umów i norm dotyczących kary śmierci. Począwszy od 1999 roku UE systematycznie składała propozycje przyjęcia przez Zgromadzenie Ogólne ONZ Rezolucji w sprawie wprowadzenia moratorium na karę śmierci. Ostatecznie w dniu 18 grudnia 2007 roku przyjęło ono Rezolucję 62/149 w sprawie moratorium na wykonywanie kary śmierci ${ }^{27}$. Natomiast w oświadczeniu prezydencji wydanym w imieniu UE w dniu 10 października 2009 roku z okazji dnia przeciw karze śmierci możemy przeczytać, że

Unia Europejska potwierdza swój absolutny sprzeciw wobec stosowania kary śmierci. Unia Europejska jest przekonana, że jej zniesienie jest integralną częścią poszanowania praw człowieka i umacnia jego godność. Kara śmierci dotyczy prawa do życia każdej osoby. Państwo — mające szczególną odpowiedzialność jako ostateczny gwarant praw człowieka wszystkich obywateli — nie powinno nikogo pozbawiać życia. Unia Europejska popiera wszelkie środki podejmowane w celu zniesienia kary śmierci ${ }^{28}$.

Wartości stanowią również centralną kategorię normatywną, na której zgodnie z art. 8 ust. 1 TUE oparta jest współpraca pomiędzy UE a państwami sąsiedzkimi w ramach Europejskiej Polityki Sąsiedztwa (EPS). Traktat nakłada na UE zobowiązanie do współpracy z państwami sąsiedzkimi, ale wyłącznie tymi, które tych wartości przestrzegają. W ramach tej polityki UE wspiera zaangażowanie państw sąsiedzkich w obszarze wartości, z tego powodu we wszystkich porozumieniach niewiążących prawnie zawartych z państwami sąsiedzkimi (takimi jak: plany działania, agendy stowarzyszeniowe oraz priorytety partnerstwa) zawarte zostały zapisy mające na celu wzmocnienie zaangażowania państw sąsiedzkich w obszarze wartości. Podkreślić jednak należy, że zaangażowanie państw sąsiedzkich w tym obszarze jest różne, a współpraca w ramach EPS ma to zmienić i doprowadzić do zwiększenia „efektywnego współdzielenia wartości”29. Za pośrednictwem tej polityki UE zobowiązała się do promowania w państwach sąsiedzkich dobrych rządów, demokracji, praw człowieka i praworządności; wspierania reform w tym obszarze oraz wspierania społeczeństwa obywatelskiego. UE aktywnie wspiera działania na rzecz promowania praworządności i wartości demokratycznych, w tym reformę sądownictwa oraz niezależność władzy sądowniczej, walkę z korupcją, ochronę praw człowieka, podstawowych wolności i dialog ze społeczeń-

27 United Nations, General Assembly, Resolution 62/149 on "Moratorium on the Use of the Death Penalty”, 18 grudnia 2007 roku, A/Res/62/149.

28 Rada Unii Europejskiej, Oświadczenie prezydencji wydanym w imieniu UE z okazji siódmego światowego i trzeciego europejskiego dnia przeciw karze śmierci, Bruksela 2009, Doc 14235/09.

29 A. Kalicka- Mikołajczyk, Prawa człowieka jako zasada uniwersalna. Wspótpraca Unii Europejskiej z krajami partnerskimi w ramach Europejskiej polityki sąsiedztwa, [w:] Z problematyki prawa międzynarodowego, europejskiego i krajowego Księga poświęcona pamięci doktora Macieja Lisa, red. B. Mielnik, Wrocław 2018, s. 33-54. 
stwem obywatelskim. Za pośrednictwem dialogu politycznego państwa UE prowadzą współpracę z państwami sąsiedzkimi w zakresie promowania poszanowania międzynarodowych zobowiązań dotyczących prawa człowieka. Demokracja, poszanowanie praw człowieka i zasady praworządności to podstawy partnerstwa UE z jej sąsiadami. Nie istnieje jednakże jeden określony model reformy tego sektora ani gotowa recepta na jej przeprowadzenie. Reformy przebiegają odmiennie w różnych państwach sąsiedzkich, ale w tworzeniu głębokiej i trwałej demokracji można dopatrzeć się kilku elementów wspólnych, wymagających silnego i trwałego zaangażowania ze strony państw sąsiedzkich. Należą do nich: wolne i sprawiedliwe wybory; wolność zrzeszania się i zgromadzeń, wolność wypowiedzi oraz wolność prasy i mediów; praworządność, na straży której stoi niezależny system sądowniczy, oraz prawo do rzetelnego procesu sądowego; walka z korupcją, reforma sektora odpowiedzialnego za zapewnienie bezpieczeństwa oraz egzekwowanie prawa (w tym policji), jak również wprowadzenie demokratycznej kontroli nad siłami zbrojnymi i siłami bezpieczeństwa.

\section{UWAGI KOŃCOWE}

Podsumowując, należy wyraźnie podkreślić, że wartości zajmują bardzo szczególne miejsce w systemie unijnego prawa. Wywodzą się one z zasad ogólnych, jednakże w przeciwieństwie do nich mają charakter bardziej syntetyczny i elementarny. Przepis art. 2 TUE ustanawia wartości, na których oparta jest UE i ich wspólnotę dla wszystkich państw członkowskich. Jest to katalog spójny i zamknięty. Jednocześnie jest podstawową regulacją materialną, do której odwołują się inne artykuły traktatu, co czyni z niej centralną kategorię normatywną dla unijnego porządku prawnego. Fakt ten oznacza, że wartości stanowią podstawę funkcjonowania UE, a ich propagowanie na arenie międzynarodowej jest zasadniczym celem organizacji. Wyznaczają one standardy ustrojowe nie tylko dla państw członkowskich, ale również dla państw trzecich, mają pozycję hierarchicznie wyższą niż zasady ogólne prawa UE. Z punktu widzenia UE wartości posiadają zarówno aspekt konstytucyjny, jak i instrumentalny. W polityce zewnętrznej UE pełnią potrójną rolę: po pierwsze wartości wymienionych w art. 2 TUE, po drugie zasad, powtórzonych w postanowieniach art. 21 ust. 1 TUE, które razem stanowią fundament tożsamości UE, i po trzecie — celów działań zewnętrznych UE wymienionych w postanowieniach art. 3 ust. 5 TUE. Jak wskazano w niniejszym artykule, UE stosuje różne instrumenty mające na celu promowanie wartości na arenie międzynarodowej. Do tych „najpopularniejszych” należy zaliczyć: instrumenty pomocy technicznej i finansowej, preferencje handlowe, bilateralne umowy międzynarodowe oraz porozumienia niewiążące prawnie. 


\section{THE EU AS A PROMOTER OF VALUES IN THE WIDER WORLD}

\section{Summary}

In Art. 3, para. 5, the Treaty on European Union (TEU) lays down the objectives of the Union in relations with the wider world, which are further explained in detail in Art. 21. In the first place, para. 5 refers to the promotion of the Union's values. The list of values can be found in Art. 2 TEU ("The Union is founded on..."), which lists the principle of democracy, the rule of law and respect for human rights, human dignity, freedom and equality. They are to be upheld and promoted by the Union in the wider world. Thus, they are directly linked to external policy. Next, the list of values in Art. 2 is repeated in Art. 3, para. 5 as objectives of the Union's external policy and in Art. 21, para. 1 as principles. This paper provides a propaedeutic analysis of those external actions of the EU which have as their main aim to promote values internationally. The main objectives of the paper are twofold: firstly, to explain the notion of values and to assess its importance within the EU's external actions, and, secondly, to investigate how the Union promotes values in international contexts. To sum up, it must be noted that the Union uses different types of instruments in order to promote values in the wider world. The Union engages in promoting its values through financial and technical instruments, trade preferences, international agreements, and, finally, non-binding international instruments.

Keywords: Union values, external policy, trade instruments, financial instruments, international agreements

\section{BIBLIOGRAFIA}

Agreement on Extradition Between the European Union and the United States of America, Dz.U. L 181 z 19 lipca 2003 roku.

Sekretariat Generalny Rady Unii Europejskiej, Bezpieczna Europa w lepszym świecie. Europejska Strategia Bezpieczeństwa, „Monitor Integracji Europejskiej” 2004, nr 70.

Cieśliński A., Wartości Unii Europejskiej jako wartości konstytucyjne, „Przegląd Prawa i Administracji” 91, 2012.

Communication from the Commission on the inclusion of respect for democratic principles and human rights in agreements between the Community and third countries, COM (95) 216 final.

Communication from the Commission to the Council and the European Parliament, The European's Union Role in promoting human rights and democracy in third countries, COM (2001) 252 final.

Cremona M., Values in EU Foreign Policy, [w:] Beyond the Established Legal Order. Policy Interconnections between the EU and the Rest of the World, red. M. Evans, P. Koutrakos, Oxford 2011.

Council of the European Union, Ensuring protection. European Union Guidelines on Human Rights Defenders, https://eeas.europa.eu/sites/eeas/files/eu_guidelines_hrd_en.pdf(dostęp: 2.01.2021).

Council of the European Union, EU Guidelines on Children and Armed Conflict, Bruksela 2008, Doc. 10019/08.

Globalna strategia na rzecz polityki zagranicznej i bezpieczeństwa UE, https://europa.eu/globalstrategy/sites/globalstrategy/files/eugs_pl_version.pdf (dostęp: 15.05.2018).

Kalicka-Mikołajczyk A., Wartości w polityce zewnętrznej Unii Europejskiej, [w:] Wspólne wartości prawa międzynarodowego, europejskiego i krajowego, red. E. Cała-Wacinkiewicz, J. Menkes, Warszawa 2018.

Kalicka- Mikołajczyk A., Prawa człowieka jako zasada uniwersalna. Wspótpraca Unii Europejskiej $z$ krajami partnerskimi w ramach europejskiej polityki sąiedztwa, [w:] Z problematyki prawa 
międzynarodowego, europejskiego i krajowego Księga poświęcona pamięci doktora Macieja Lisa, red. B. Mielnik, Wrocław 2018.

Lenaerts K., Wartości Unii Europejskiej a pluralizm konstytucyjny, „Europejski Przegląd Sądowy” 2014, $\mathrm{nr} 9$.

Mik C., Traktato Unii Europejskiej. Komentarz, Łódź 2005.

Pikuła Ł.J., Aksjologia Unii Europejskiej w świetle źródel, wyktadni i instytucji, Toruń 2015.

Rada Unii Europejskiej, Wytyczne w sprawie dialogu na temat praw czlowieka prowadzonego z państwami trzecimi, Bruksela 2008, Doc. 16526/08.

Rada Unii Europejskiej, Wytyczne UE w sprawie praw czlowieka dotyczace niedyskryminacji w działaniach zewnętrznych, Bruksela 2019, Doc. 6337/19.

Rada Unii Europejskiej, Wytyczne w sprawie kary śmierci: wersja zweryfikowana i uaktualniona, Bruksela 2008, Doc. 10015/08.

Rada Unii Europejskiej, Oświadczenie prezydencji wydanym w imieniu UE z okazji siódmego światowego i trzeciego europejskiego dnia przeciw karze śmierci, Bruksela 2009, Doc 14235/09.

Rozporządzenie Parlamentu Europejskiego i Rady (UE) nr 978/2012 z dnia 25 października 2012 roku wprowadzające ogólny system preferencji taryfowych i uchylające rozporządzenie Rady (WE) nr 732/2008, Dz.U. L 303 z 31 października 2012 roku, s. 1-82.

Rozporządzenie Parlamentu Europejskiego i Rady (UE) nr 235/2014 z dnia 11 marca 2014 roku ustanawiające instrument finansowy na rzecz wspierania demokracji i praw człowieka na świecie, Dz.U. L 77 z 15 marca 2014 roku, s. 85-94.

Sprawa C-268/94, Portugalia p. Radzie, ECLI:EU:C:1996:461.

Sprawa C-162/96, A. Racke GmbH \& Co. p. Hauptzollamt Mainz, ECLI:EU:C:1998:293.

Sprawa C-112/00, Eugen Schmidberger, Internationale Transporte und Planzüge p. Republik Österreich, ECLI:EU:C:2003:333.

Sprawa C-438/05, International Transport Workers' Federation i Finnish Seamen's Union p. Viking Line ABP $i$ OÜ Viking Line Eesti, ECLI:EU:C:2007:772.

Sprawy połączone C-402/05 P oraz C-415/05 P, Yassin Abdullah Kadi i Al Barakaat International Foundation p. Radzie Unii Europejskiej i Komisja Wspólnot Europejskich, ECLI:EU:C:2008:461.

Sprawa C-263/14, Parlament p. Radzie, ECLI:EU:C:2016:435.

Traktat o Unii Europejskiej (wersja skonsolidowana z 2016 roku), Dz.U. C 2002 z 7 czerwca 2016 roku.

United Nations, General Assembly, Resolution 62/149 on Moratorium on the use of the death penalty, 18.12. 2007, A/Res/62/149.

Updated European Union Guidelines on promoting compliance with international humanitarian law (IHL), Dz.U. C 303 z 15 grudnia 2009 roku, s. 12-17.

Wymiana listów między Unią Europejską a rządem Kenii w sprawie warunków i trybu przekazywania Kenii przez EUNAVFOR osób podejrzanych o popełnienie aktów piractwa przetrzymywanych przez siły morskie dowodzone przez Unię Europejską (EUNAVFOR) oraz zajętego mienia będącego w posiadaniu EUNAVFOR-u, a także traktowania osób i mienia po takim przekazaniu, Dz.U. L 79 z 25 marca 2009 roku, s. 47-59.

Zieliński M., Pojęcie i rodzaje polityk Wspólnoty Europejskiej, [w:] Polska i Wielka Brytania wobec Unii Europejskiej. Wybrane zagadnienia prawne, red. G. Grabowska, Katowice 2002.

Zieliński M., Wartości Unii Europejskiej, [w:] Ubi Ius, Ibi Remedium. Księga dedykowana pamięci Profesora Jana Kolasy, red. B. Krzan, Wrocław 2016. 